\title{
Hierarchical mesoporous ZSM-5 for the dehydration of methanol to dimethyl ether
}

\author{
Qi Yang a, Haitao Zhang b, Meng Kong a , Xiuxiu Bao a, Jinhua Fei a,*, Xiaoming Zheng a \\ a Institute of Catalysis, Key Laboratory of Applied Chemistry of Zhejiang Province, Zhejiang University, Hangzhou 310028, Zhejiang, China \\ b Petrochina Lanzhou Chemical Research Centre, Lanzhou 730060, Gansu, China
}

\section{A R T I C L E I N F O}

\section{Article history:}

Received 5 March 2013

Accepted 13 May 2013

Published 20 August 2013

Keywords:

Hierarchical mesopore

HZSM-5 zeolite

Surface acidity

Methanol dehydration

Dimethyl ether

\begin{abstract}
A B S T R A C T
Hierarchical mesoporous ZSM-5 zeolites were synthesized using small organic cations of tetrapropylammonium and meso-sized cationic polymers of dimethyldiallyl ammonium chloride acrylamide copolymer as templates. The zeolites were used for the dehydration of methanol to dimethyl ether (DME). Characterization results showed that the basic MFI-type structure was still obtained after adding the cationic polymers, while their nitrogen isotherms exhibited a broad hysteresis loop at relative pressures higher than 0.4 , which proved the presence of mesopores. The mesoporosity of the hierarchical mesoporous ZSM- 5 can be adjusted simply by adding different amounts of the cationic polymer. Catalytic tests showed that the hierarchical mesoporous HZSM-5 zeolites exhibited better stability than conventional HZSM-5 and excellent DME selectivity. The activity for methanol dehydration strongly depended on the textural property and acidity of the catalyst.
\end{abstract}

(C) 2013, Dalian Institute of Chemical Physics, Chinese Academy of Sciences. Published by Elsevier B.V. All rights reserved.

\section{Introduction}

Dimethyl ether (DME) has attracted much attention as an alternative and clean diesel fuel because of its extremely lower levels of nitrogen oxide $\left(\mathrm{NO}_{x}\right)$ emission, near zero smoke, and less engine noise [1,2]. DME can also be used as an intermediate raw material for the production of chemicals such as light olefins, conventional fuels, dimethyl sulfate, and methyl acetate [3]. DME is commercially produced by methanol dehydration (MTD process) because of the availability of huge quantities of methanol produced from syngas, a mixture of $\mathrm{CO}$ and $\mathrm{H}_{2}$, which in turn, is made from biomass, natural gas, and coal [4,5]. In the 1980s, the STD process (syngas to DME) was also developed $[6,7]$, in which DME is synthesized directly from syngas in a single reactor over a hybrid catalyst comprising a methanol synthesis catalyst and a methanol dehydration catalyst. The main reactions in the STD process are:

$$
\begin{array}{ccrl}
\mathrm{CO}+2 \mathrm{H}_{2} \leftrightarrow \mathrm{CH}_{3} \mathrm{OH} & \Delta H=-90.6 \mathrm{~kJ} / \mathrm{mol} \\
2 \mathrm{CH}_{3} \mathrm{OH} \leftrightarrow \mathrm{CH}_{3} \mathrm{OCH}_{3}+\mathrm{H}_{2} \mathrm{O} & \Delta H=-23.4 \mathrm{~kJ} / \mathrm{mol} \\
2 \mathrm{CO}+4 \mathrm{H}_{2} \leftrightarrow \mathrm{CH}_{3} \mathrm{OCH}_{3}+\mathrm{H}_{2} \mathrm{O} & \Delta H=-207.4 \mathrm{~kJ} / \mathrm{mol} \\
\mathrm{CO}+\mathrm{H}_{2} \mathrm{O} \leftrightarrow \mathrm{H}_{2}+\mathrm{CO}_{2} & \Delta H=-41.2 \mathrm{~kJ} / \mathrm{mol} \\
3 \mathrm{CO}+3 \mathrm{H}_{2} \leftrightarrow \mathrm{CH}_{3} \mathrm{OCH}_{3}+\mathrm{CO}_{2} & \Delta H=-245.8 \mathrm{~kJ} / \mathrm{mol}
\end{array}
$$
syngas to methanol (Eq. (1)) followed by MTD (Eq. (2)) process, the direct synthesis process (Eq. (3) and/or Eq. (5)) is more favorable thermodynamically [8]. For this reason, much more attention has been paid to this process from the consideration of equilibrium conversion.

Although high CO conversion in the STD process over the hybrid catalysts composed of the methanol synthesis catalyst and the methanol dehydration catalyst have been reported in published papers [9-11], the optimum catalytic reaction temperatures for the methanol synthesis catalyst and methanol dehydration catalyst are different. Therefore, it is still difficult

\footnotetext{
* Corresponding author. Tel/Fax: +86-571-88273283; E-mail: jhfei@zju.edu.cn

This work was supported by the National Basic Research Program of China (973 Program, 2007CB210207, 2013CB228104) and the High Technology Research and Development Program of China (863 Program, 2007AA05Z415). 
to operate the STD process in a way that ensures the two reactions both have high activity and selectivity simultaneously. The most frequently used industrial catalyst for methanol synthesis is $\mathrm{CuO}-\mathrm{ZnO}-\mathrm{Al}_{2} \mathrm{O}_{3}$, which gives high activity and selectivity at $270-290{ }^{\circ} \mathrm{C}[12,13]$. The industrial methanol dehydration process is generally catalyzed by $\gamma-\mathrm{Al}_{2} \mathrm{O}_{3}$ at above $300{ }^{\circ} \mathrm{C}$, but because of the weak acidity of $\gamma-\mathrm{Al}_{2} \mathrm{O}_{3}$ [3], HZSM-5, HY, SAPO, and other microporous zeolites with moderate acidity have also been used for methanol dehydration at $250-400{ }^{\circ} \mathrm{C}$ $[2,5,14]$. Unfortunately, undesirable byproducts (hydrocarbons, cokes, etc.) are produced over most of these zeolite catalysts at reaction temperatures higher than $260{ }^{\circ} \mathrm{C}$ [12]. Although HZSM-5 is an effective dehydration catalyst, it leads to the formation of byproducts at high reaction temperatures [15].

There are two main reasons for the quick loss in catalytic activity and selectivity on these microporous zeolite catalysts. First, the existence of strong acidic sites on the zeolite surface causes deactivation $[16,17]$. Undesirable byproducts in DME synthesis such as hydrocarbons and even coke are formed on the zeolite surface due to the presence of these strong acidic sites, which hinder access to the acid sites and plug the zeolite pores [2]. Consequently, many researchers have put in efforts to moderate the acidity of zeolites with satisfactory results $[18,19]$. Mao et al. $[9,20]$ reported that after modification with a suitable amount of MgO, modified HZSM-5 showed decreased byproduct selectivity and increased DME selectivity due to the removal of strong acidic sites. Modifying strong acid sites on the surface of HZSM-5 with $\mathrm{Al}, \mathrm{Zr}, \mathrm{Na}$, and $\mathrm{Zn}$ oxides also depressed byproduct formation and enhanced DME selectivity [21]. To some degree, this problem was solved. The second reason for deactivation arises from the small microporous channels in the zeolite [12,22]. However, this factor is often not emphasized because acidity is usually considered to be the main property of the catalyst. DME cannot diffuse quickly enough in the narrow and slender micropore and this consequently severely limits the activity. Mesoporous zeolites like MCM-41 have pore diameters from 1.5 to10 nm, but unfortunately, which have poor acidity and poor hydrothermal stability as compared to microporous HZSM-5 zeolite [12,23] Therefore, it would be advantageous to develop a solid acid catalyst with the proper acidity and which also has the large channel advantage of a mesoporous zeolite.

In this work, a series of hierarchical mesoporous ZSM-5 zeolites were synthesized. The effects of the hierarchical mesopores and acidity properties on catalytic performance in the MTD process were studied. The properties of these catalysts were characterized by X-ray diffraction (XRD), $\mathrm{N}_{2}$ adsorption, inductively coupled plasma atomic emission spectrometry (ICP-AES), scanning electron microscopy (SEM), transmission electron microscopy (TEM), and $\mathrm{NH}_{3}$-temperature programmed desorption ( $\left.\mathrm{NH}_{3}-\mathrm{TPD}\right)$.

\section{Experimental}

\subsection{Synthesis of the zeolites}

The hierarchical porous ZSM-5 zeolites were synthesized according to the literature [24]. First, $0.3 \mathrm{~g}$ of $\mathrm{NaAlO}_{2}, 41.5 \mathrm{ml}$ of tetrapropylammonium hydroxide (TPAOH, $19.5 \mathrm{wt} \%), 26.25$ $\mathrm{ml}$ of tetraethyl orthosilicate (TEOS), and $71.5 \mathrm{ml}$ of $\mathrm{H}_{2} \mathrm{O}$ were mixed together under stirring and aged at $100{ }^{\circ} \mathrm{C}$ for $3 \mathrm{~h}$. Then, cationic dimethyldiallyl ammonium chloride acrylamide copolymer (PDDA, $10 \mathrm{wt} \%$, molecular weight about $2.6 \times 10^{6}$ ) was introduced into the above solution under vigorous stirring. The new mixture with $2.0,3.0$, or $4.0 \mathrm{~g}$ of polymer added was transferred into an autoclave for further hydrothermal treatment at $180^{\circ} \mathrm{C}$ for $7-10 \mathrm{~d}$. After crystallization, the product was collected by filtration, washed with demineralized water, dried in air, and then calcined at $550{ }^{\circ} \mathrm{C}$ for $5 \mathrm{~h}$ to remove the template. Finally, the NaZSM-5 samples obtained were ion exchanged three times with $\mathrm{NH}_{4} \mathrm{NO}_{3}$ solution $(1.0 \mathrm{~mol} / \mathrm{L})$ at $80^{\circ} \mathrm{C}$, followed by filtering, washing, drying, and calcining in air at $500{ }^{\circ} \mathrm{C}$ for $3 \mathrm{~h}$ to get the HZSM- 5 samples. The HZSM- 5 samples obtained were denoted as HZ- $x$, where $x$ was the amount of polymer added, which was $2.0,3.0$, and 4.0 g, respectively.

For comparison, a conventional HZSM-5 zeolite was synthesized using a similar procedure but without adding the cationic polymer, which was denoted as HZ-0. Another conventional HZSM-5 zeolite was also synthesized by this method, where the amount of $\mathrm{NaAlO}_{2}$ was changed to $0.15 \mathrm{~g}$, denoted as HZ-c.

\subsection{Characterization}

XRD analysis was performed on a Rigaku D/MAX 2550/PC diffractometer with $\mathrm{Ni}$ filtered $\mathrm{Cu} K_{\alpha}$ radiation operated at 40 $\mathrm{kV}$ and $100 \mathrm{~mA}$. SEM experiments were performed on Hitachi S-4000 and Hitachi SU-70 electron microscopes. The surface area and pore volume measurements of the samples were conducted on a volumetric adsorption apparatus (ASAP 2020M, Micromeritics) at $-196{ }^{\circ} \mathrm{C}$ using liquid $\mathrm{N}_{2}$. The samples were degassed at $300{ }^{\circ} \mathrm{C}$ for $4 \mathrm{~h}$ before the measurements. TEM experiments were performed on a FEI Tecnai G2 F20 S-TWIN microscope operating at $200 \mathrm{kV}$. The sample compositions were determined by ICP-AES with a Perkin-Elmer 3300DV emission spectrometer.

$\mathrm{NH}_{3}$-TPD was used to determine the acidity of the samples. Typically, $0.2 \mathrm{~g}$ of sample (40-60 mesh) was pretreated at 500 ${ }^{\circ} \mathrm{C}$ in a $\mathrm{N}_{2}$ flow for 60 min and then saturated with $\mathrm{NH}_{3}$ at 100 ${ }^{\circ} \mathrm{C}$ for $30 \mathrm{~min}$. After saturation, the sample was purged by $\mathrm{N}_{2}$ flow to remove physically adsorbed $\mathrm{NH}_{3}$. Finally, desorption of $\mathrm{NH}_{3}$ was carried out from 100 to $600{ }^{\circ} \mathrm{C}$ with a heating rate of $10{ }^{\circ} \mathrm{C} / \mathrm{min}$. Desorbed $\mathrm{NH}_{3}$ was monitored continuously as a function of desorption temperature by a TCD detector. The amount of coke deposited on the used samples was determined on a thermogravimetric analyzer (TGA). The used samples were pretreated at $300{ }^{\circ} \mathrm{C}$ in $\mathrm{N}_{2}$ for $30 \mathrm{~min}$, then cooled to 100 ${ }^{\circ} \mathrm{C}$, and finally heated from 100 to $850{ }^{\circ} \mathrm{C}$ at a rate of $10{ }^{\circ} \mathrm{C} / \mathrm{min}$ in $20 \% \mathrm{O}_{2} / \mathrm{N}_{2}(50 \mathrm{ml} / \mathrm{min})$.

\subsection{Catalytic activity tests}

Methanol dehydration was carried out in a quartz fixed-bed reactor with an inner diameter of $8 \mathrm{~mm}$. The sample $(0.5 \mathrm{~g}$, 40-60 mesh) was placed in the reactor, pretreated in a stream 
of $\mathrm{N}_{2}$ at $300{ }^{\circ} \mathrm{C}$ for $2 \mathrm{~h}$, and then cooled to the reaction temperature of $260{ }^{\circ} \mathrm{C}$, which was followed by the introduction of gaseous methanol mixed with $\mathrm{N}_{2}$ into the reactor. The flow rate of methanol was controlled by a micro-liquid pump to give the liquid hourly space velocity (LHSV) of $0.6 \mathrm{~h}^{-1}$. The products in the effluent were analyzed by an online gas chromatograph (HP 5890) equipped with a Poropak Q column and a TCD detector.

\section{Results and discussion}

\subsection{Physicochemical properties of the synthesized zeolites}

Figure 1 shows XRD patterns of the samples. The HZ-2, HZ-3, and HZ-4 samples showed similar XRD patterns to that of conventional HZSM-5, suggesting that the basic MFI-type structure was still obtained after adding different amounts of cationic polymer PDDA. Compared with HZ-0 (100\%), the relative crystallinities of HZ-2, HZ-3, and HZ-4 were estimated from the XRD result as $94 \%, 89 \%$, and $87 \%$, respectively. The results indicate the successful crystallization of HZSM-5 zeolite after adding the cationic polymer into the synthesis gel.

The SEM images (Fig. 2) showed the morphology of the zeolites. All the samples showed a hexagonal column-like crystal

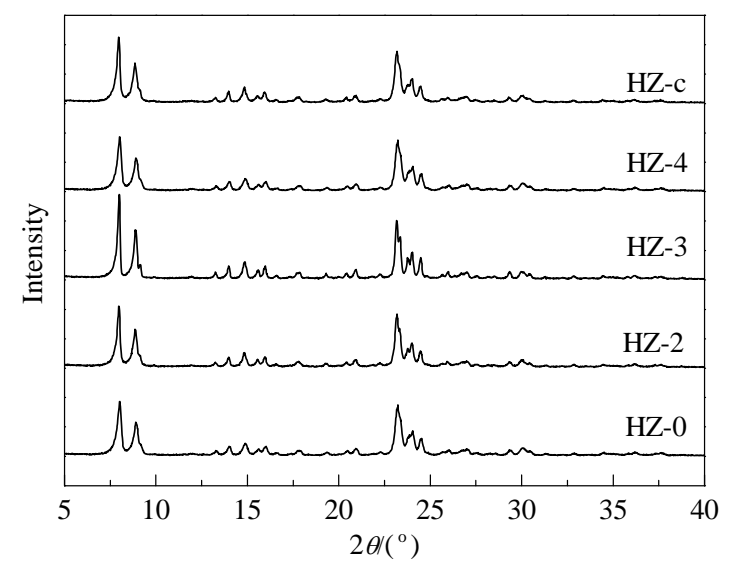

Fig. 1. XRD patterns of the HZSM-5 samples.
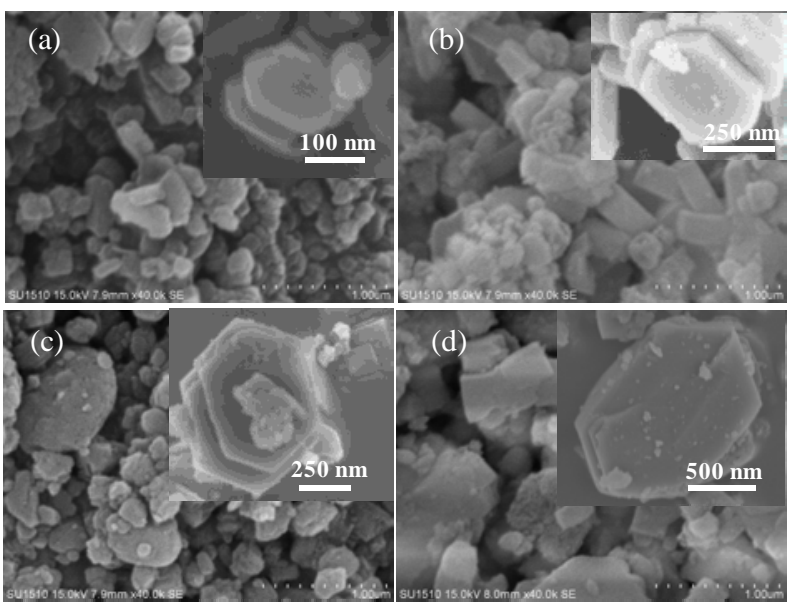

Fig. 2. SEM images of the HZSM-5 samples. (a) HZ-0; (b) HZ-2; (c) HZ-3; (d) HZ-4.

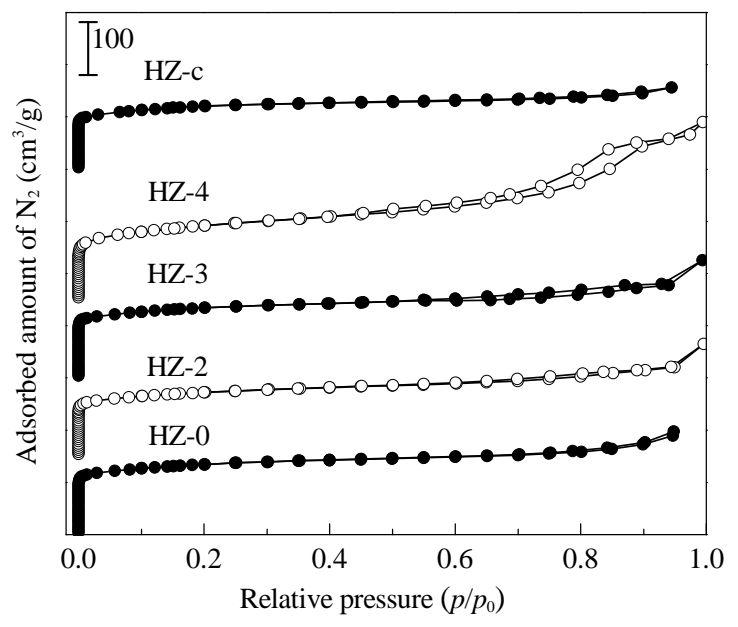

Fig. 3. $\mathrm{N}_{2}$ adsorption-desorption isotherms of the HZSM-5 samples.

morphology, indicating that crystal morphology was almost not affected by the cationic polymer added into the synthesis gel. However, the average grain size increased with the amount of polymer added, and a very small amount of amorphous material appeared on the surface of the zeolite particles.

Figure 3 shows $\mathrm{N}_{2}$ adsorption-desorption isotherms of the samples. All the samples showed significant uptake at $p / p_{0}<$ 0.1 , indicating the presence of micropores. Compared with conventional HZ-0, all of the synthesized hierarchical mesoporous HZSM-5 samples exhibited a hysteresis loop at $p / p_{0}>0.4$, suggesting the presence of hierarchical mesopores $[25,26]$.

The textural properties of the samples are summarized in Table 1. The data showed that the micropore volume and micropore surface area decreased with the increased amount of polymer added, while the mesopore volume and mesopore surface area increased. This indicates that the added polymer resulted in a larger pore volume in the HZSM-5 samples, and the mesoporosity of the HZSM-5 zeolite can be simply adjusted by adding different amounts of the cationic polymers. However, the zeolite is quite small and the zeolite crystal size is so small that they can be considered as part of the mesoporous surface area [27]. Therefore, it is difficult to unambiguously confirm the existence of "true" hierarchical mesopores in the zeolites based solely on $\mathrm{N}_{2}$ adsorption-desorption isotherms.

TEM is the ultimate technique for determining whether a synthesized hierarchical mesoporous zeolite is a "true" hierarchical mesoporous material with zeolitic walls [24,27]. Based on the result of $\mathrm{N}_{2}$ adsorption-desorption isotherms, HZ-3 was chosen for TEM study, and HZ-0 was also studied for comparison. As shown in Fig. 4, only ordered micropores can be seen in

Table 1

Textural properties of the HZSM-5 samples.

\begin{tabular}{lccccccc}
\hline \multirow{2}{*}{ Catalyst } & \multicolumn{3}{c}{$A_{\mathrm{BET}} /\left(\mathrm{m}^{2} / \mathrm{g}\right)$} & & \multicolumn{3}{c}{ Pore volume $\left(\mathrm{cm}^{3} / \mathrm{g}\right)$} \\
\cline { 2 - 4 } \cline { 7 - 8 } & Total & Micropore & Mesopore & & Total & Micropore & Mesopore \\
\hline HZ-0 & 412 & 401 & 11 & & 0.23 & 0.20 & 0.03 \\
HZ-2 & 418 & 398 & 20 & & 0.25 & 0.19 & 0.06 \\
HZ-3 & 415 & 366 & 49 & & 0.28 & 0.18 & 0.10 \\
HZ-4 & 476 & 221 & 255 & & 0.31 & 0.11 & 0.20 \\
HZ-c & 410 & 393 & 17 & & 0.22 & 0.19 & 0.03 \\
\hline
\end{tabular}



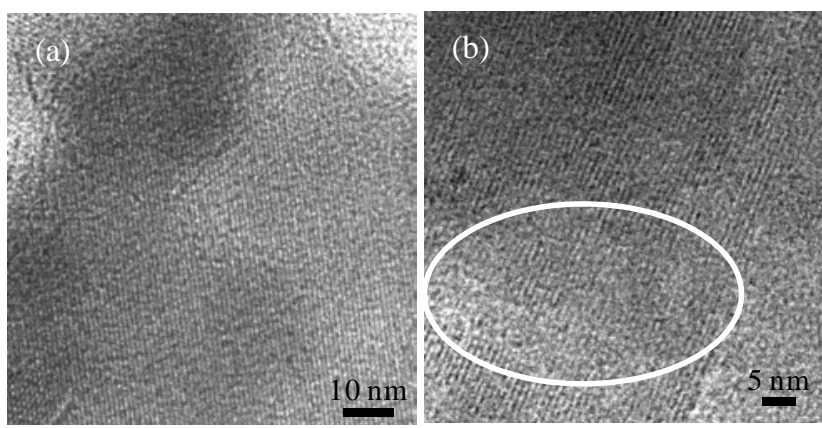

Fig. 4. TEM images of the HZSM-5 samples. (a) HZ-0; (b) HZ-3.

HZ-0. However, in HZ-3, both ordered micropores and a disordered hierarchical mesoporosity can be easily seen. The ordered micropores of the crystal are reasonably attributed to the typical micropores of ZSM-5 crystals. This result confirmed the "true" hierarchical structures in the synthesized HZ- $x$ zeolites where the different amounts of cationic polymers were added as the meso-structure directing agents. From the literature, we know that these hierarchical mesopores are useful for faster mass transport of reactants and products in catalysis $[24,28]$.

\subsection{Surface acidity of the synthesized zeolites}

The surface acidity of the synthesized zeolites determined by $\mathrm{NH}_{3}$-TPD is depicted in Fig. 5. All samples exhibit two $\mathrm{NH}_{3}$ desorption peaks at 200 and $400{ }^{\circ} \mathrm{C}$, corresponding to $\mathrm{NH}_{3}$ eluted from weak and strong acid sites, respectively, which was consistent with reported results $[29,30]$. Compared with conventional HZ-0, both of the two peaks of these catalysts decreased with added amounts of polymers, indicating the decreased amount of surface acid sites. Table 2 presents the estimated acid site concentrations on the various samples. Notably, conventional zeolite, HZ-0, exhibited the highest acidic concentration. The order of total acidity was HZ-0 > HZ-2 $\approx \mathrm{HZ}-\mathrm{C}>$ HZ-3 > HZ-4, while the order of the weak/strong ratio was HZ-4 $>\mathrm{HZ}-3$ > HZ-C > HZ-2 > HZ-0. The Si/Al ratios of HZ-0, HZ-2, HZ-3, and HZ-4 measured with the ICP-AES analysis were 43,

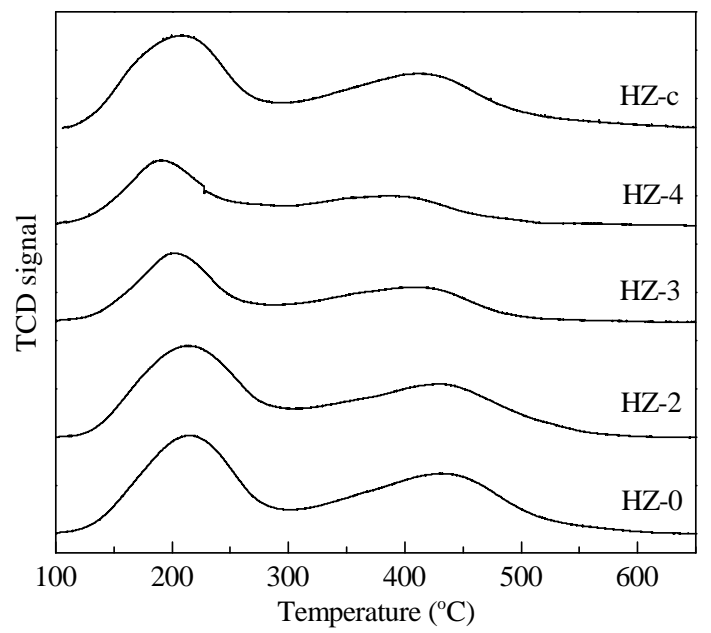

Fig. 5. $\mathrm{NH}_{3}$-TPD profiles of the synthesized HZSM-5 samples.
Table 2

Estimated acidic sites on the HZSM-5 samples.

\begin{tabular}{|c|c|c|c|c|c|}
\hline \multirow{2}{*}{ Sample } & \multicolumn{3}{|c|}{ Amounts of the acid sites a $(\mathrm{mmol} / \mathrm{g})$} & \multirow{2}{*}{$\begin{array}{l}\text { Weak/ } \\
\text { Strong }\end{array}$} & \multirow{2}{*}{$\begin{array}{c}\mathrm{Si} / \mathrm{Al} \\
\text { atom ratio }\end{array}$} \\
\hline & Weak & Strong & Total & & \\
\hline $\mathrm{HZ}-\mathrm{O}$ & 0.407 & 0.405 & 0.812 & 1.01 & 43 \\
\hline HZ-2 & 0.389 & 0.363 & 0.752 & 1.08 & 44 \\
\hline $\mathrm{HZ}-3$ & 0.238 & 0.196 & 0.434 & 1.21 & 49 \\
\hline $\mathrm{HZ}-4$ & 0.237 & 0.159 & 0.396 & 1.49 & 48 \\
\hline $\mathrm{HZ}-\mathrm{C}$ & 0.399 & 0.352 & 0.751 & 1.13 & - \\
\hline
\end{tabular}

a Estimated by $\mathrm{NH}_{3}$-TPD curves, and weakly and strongly acidic sites are ranged in the region of $100-300{ }^{\circ} \mathrm{C}$ and $300-600{ }^{\circ} \mathrm{C}$, respectively. ${ }^{\mathrm{b}}$ Analyzed by ICP.

44,49 , and 48 , respectively. The increased $\mathrm{Si} / \mathrm{Al}$ ratio and decreased relative crystallinity may be the reason for the low total acidity of HZ-3 and HZ-4 [31].

\subsection{Evaluation of catalytic performance}

Figure 6 shows the activity, stability, and selectivity in MTD reaction over various HZSM-5 samples. In order to properly reflect the byproducts produced and show more clearly the effect of pore structure and acidity, a low LHSV of $0.6 \mathrm{~h}^{-1}$ and $260{ }^{\circ} \mathrm{C}$ were chosen to evaluate the catalytic properties. Fig. 6(a) shows that all the samples initially exhibited methanol conversion values close to equilibrium at $260{ }^{\circ} \mathrm{C}$. For conventional HZ-0, during a period of $5 \mathrm{~h}$, the conversion of methanol decreased quickly from $93 \%$ to $88 \%$ at the early stage, and then decreased slowly with further reaction time increase. However, for the hierarchical mesoporous HZ- $x$ samples, the conversion of methanol remained at nearly 93\%, except for the HZ-2 sample, which showed a very slight decrease in the conversion of methanol.

Generally, a small size of the crystals can overcome the diffusion limitation of micropores and give enhanced zeolite properties such as increased surface area and decreased diffusion path lengths, which result in higher activity in the reactions than large crystals [32,33]. However, HZ-0 showed the smallest particle size but the worst catalytic activity. This indicates that the morphology or the particle size was not the main reason for the deactivation in this case.

In the literature $[16,18,19,34]$, a large amount of total acid sites and strong acid sites were recognized as a main cause for undesirable byproducts in DME synthesis, such as hydrocarbons and even coke, which in turn affect the catalytic activity. However, we cannot consider that the decreased amount of surface acid sites of the hierarchical mesoporous HZ- $x$ samples is the only reason for their excellent catalytic performance, because HZ-c had nearly the same surface acidity as HZ-2, but the results showed that HZ-c displayed a similar trend to the conventional HZ-0 sample. The conversion of methanol also decreased quickly from $93 \%$ to $89 \%$ with the HZ-c sample at the early stage, followed by a slower decrease. This result suggests that the hierarchical mesopores in the samples also was an important factor for the excellent catalytic performance in the MTD process.

Figure 6(b) shows the DME selectivity of these samples. During the reaction time of $5 \mathrm{~h}$, DME selectivity rapidly de- 

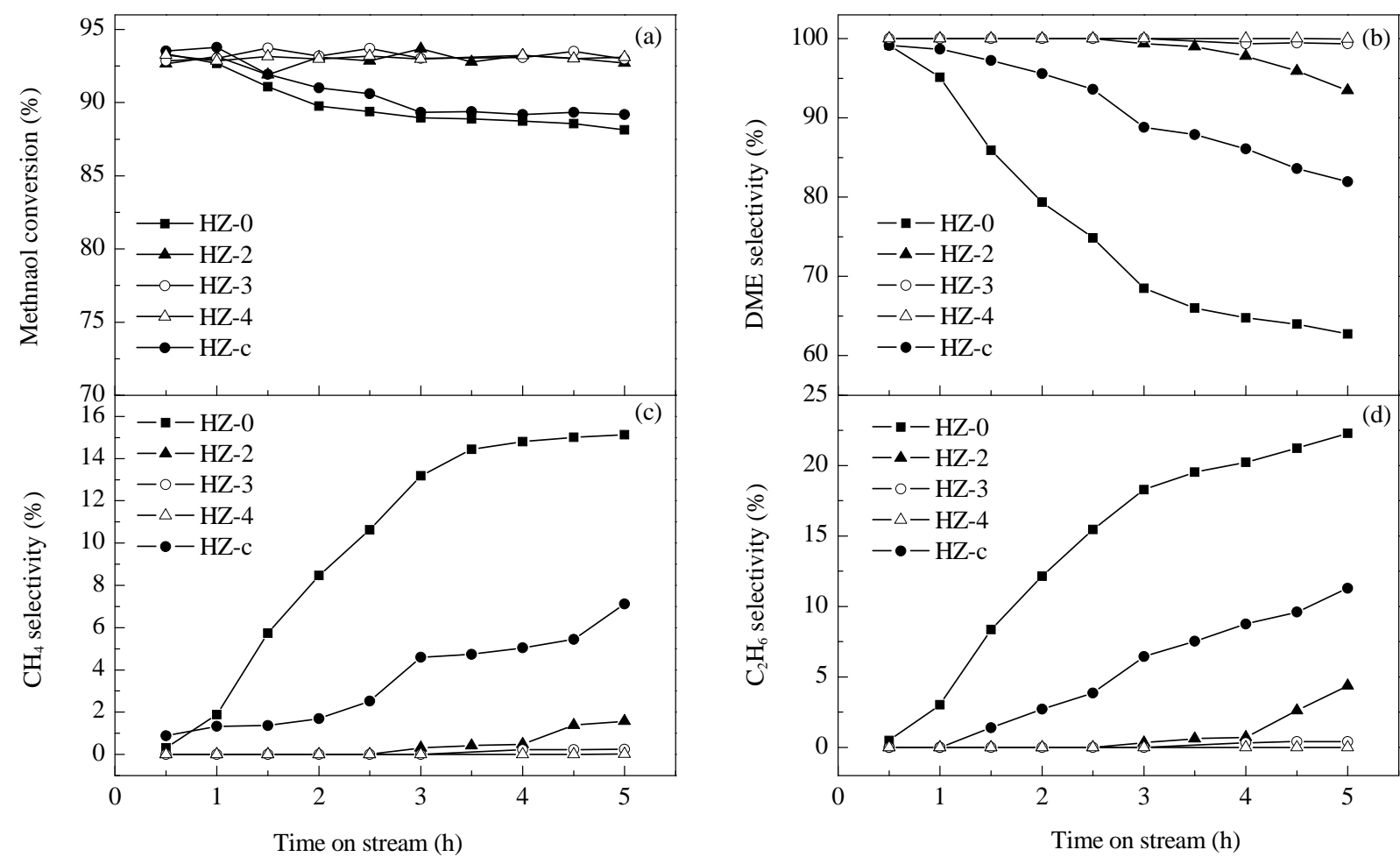

Fig. 6. Methanol dehydration performance over the various HZSM- 5 samples. Reaction conditions: $260^{\circ} \mathrm{C}, \mathrm{LHSV}=0.6 \mathrm{~h}^{-1}$.

creased from $99.2 \%$ to $62.8 \%$ over the conventional HZ-0, while the selectivity for byproducts $\mathrm{CH}_{4}$ and $\mathrm{C}_{2} \mathrm{H}_{6}$ (Fig. 6(c) and (d)) increased from $0.3 \%$ to $15.1 \%$ and $0.5 \%$ to $22.3 \%$, respectively. However, HZ-4 showed nearly $100 \%$ selectivity for DME for all the reaction times. After $5 \mathrm{~h}$ reaction, the order of DME selectivity was HZ-4 > HZ-3 > HZ-2 > HZ-c > HZ-0, while the selectivity for the byproducts $\mathrm{CH}_{4}$ and $\mathrm{C}_{2} \mathrm{H}_{6}$ showed the opposite trend (Fig. 6(c) and (d)). This indicates that the catalytic activity for MTD strongly depends on the total acidity and the mesopore volume and mesopore surface area of the sample. The sequence for HZ-2 and HZ-c should be attributed to the existence of mesopores in the HZ-2 sample.

The TGA results (Fig. 7) indicated the amounts of coke de-

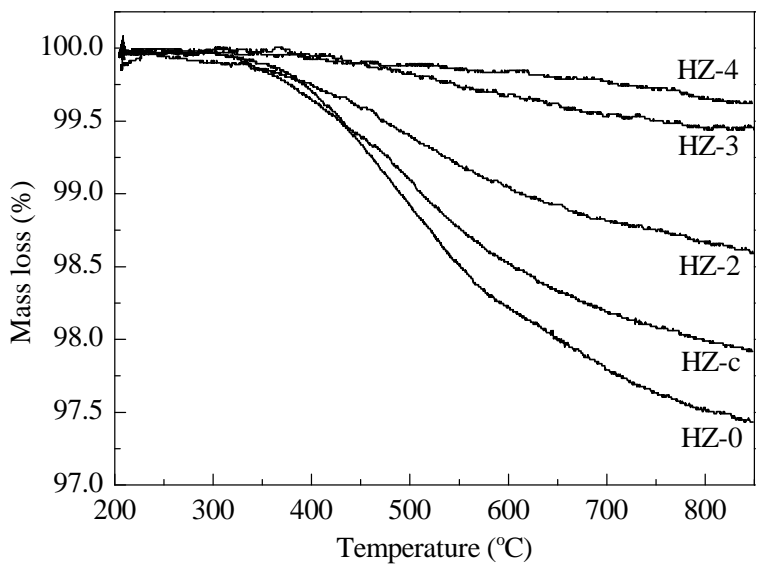

Fig. 7. TGA curves of spent HZSM- 5 samples after reaction on stream for $5 \mathrm{~h}$. Reaction conditions: $260^{\circ} \mathrm{C}$, LHSV $=0.6 \mathrm{~h}^{-1}$. posited on the samples after reaction at $260{ }^{\circ} \mathrm{C}$ for $5 \mathrm{~h}$. The order of the amount of coke deposits is the same as that of the selectivity for byproducts $\mathrm{CH}_{4}$ and $\mathrm{C}_{2} \mathrm{H}_{6}$. It agrees that microporous HZSM-5 zeolite with a high ratio of weak and strong acid sites is more resistant to coke in the MTD process [15]. Actually, both of the two conventional HZ-0 and HZ-c samples showed heavier coke deposition than the hierarchical mesoporous HZ- $x$ samples. HZ-2 was much more resistant to coke than HZ-c, even though the weak/strong acid site ratio of HZ-c was similar with that of HZ-2. This result further emphasized that the presence of mesopores in the samples effectively improved the diffusion rates of reactants and products, thus leading to less byproducts and longer catalyst life. Therefore, it can be concluded the activity for methanol dehydration strongly depends on the pore structure and surface acid property of the sample. In this work, HZ-4 with a relatively high weak/strong acid site ratio (1.49), suitable amount of total acidity $(0.237$ mmol/g), and large mesopore volume $\left(0.44 \mathrm{~cm}^{3} / \mathrm{g}\right)$ showed excellent catalytic performance under the operating conditions.

\section{Conclusions}

A series of hierarchical mesoporous HZSM-5 zeolites that integrated features of microporous zeolites (highly active sites and hydrothermal stability) and mesoporous materials (fast mass transport) were successfully synthesized using a cationic polymer as the meso-structure directing agent. As compared to conventional HZSM-5, the mesopore volume and surface area of the hierarchical mesoporous HZSM-5 increased with the increasing amounts of cationic polymer added. Under the operating conditions, the hierarchical mesoporous HZSM-5 zeolite 


\section{Graphical Abstract}

Chin. J. Catal., 2013, 34: 1576-1582 doi: 10.1016/S1872-2067(12)60621-4

\section{Hierarchical mesoporous ZSM-5 for the dehydration of methanol to dimethyl ether}

Qi Yang, Haitao Zhang, Meng Kong, Xiuxiu Bao, Jinhua Fei*, Xiaoming Zheng

Zhejiang University;

Petrochina Lanzhou Chemical Research Centre

The synthesized hierarchical mesoporous HZSM-5 zeolites exhibited better catalytic activity than conventional HZSM-5, indicating that hierarchical mesopores play an important role in the methanol to dimethyl ether process.
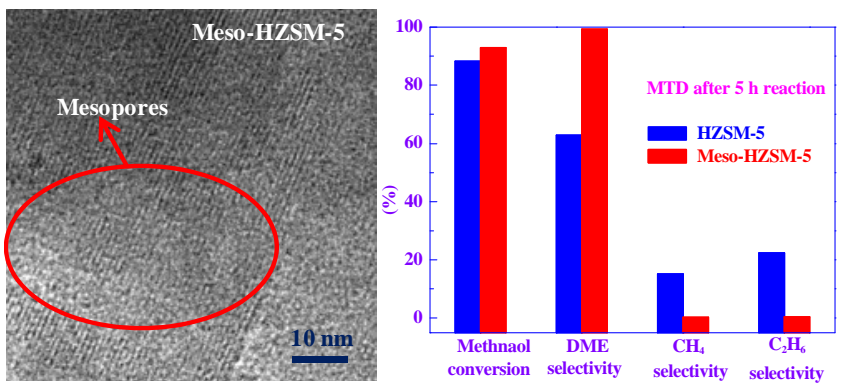

prepared with $4.0 \mathrm{~g}$ polymer showed excellent stability and high selectivity in the dehydration of methanol to DME due to the relative high weak/strong acid site ratio, suitable amount of total acidity, and large mesopore volume. These results suggest that a zeolite catalyst with the proper acidity and which also has the large channel advantage of a mesoporous zeolite can give excellent performance in the methanol dehydration process.

\section{Acknowledgments}

We thank the Center of Electron Microscope at Zhejiang University for help with the TEM experiments.

\section{References}

[1] Atkins M P, Earle M J, Seddon K R, Swadzba-Kwasny M, Vanoye L. Chem Commum, 2010, 46: 1745

[2] Laugel G, Nitsch X, Ocampo F, Louis B. Appl Catal A, 2011, 402: 139

[3] Zhang L W, Wang J H, Wu P, Hou Z Y, Fei J H, Zheng X M. Chin J Catal (张立伟, 王军华, 吴佩, 侯昭)幻, 费金华, 郑小明. 催化学报) 2010, 31: 987

[4] Hosseini S, Taghizadeh M, Eliassi A.J Nat Gas Chem, 2012, 21: 344

[5] Aboul-Fotouh S M K, Aboul-Gheit N A K, Hassan M M I. Chin J Catal (催化学报), 2011, 32: 412

[6] Yang X Y, Sun S, Ding J J, Zhang Y, Zhang M M, Gao C, Bao J. Acta Phys-Chim Sin (杨晓艳, 孙松, 丁建军, 张义, 张曼曼, 高琛, 鲍骏. 物理化学学报), 2012, 28: 1957

[7] Tang X J, Fei J H, Hou Z Y, Zheng X M, Lou H. Energy Fuels, 2008, 22: 2877

[8] Fei J H, Yang M X, Hou Z Y, Zheng X M. Energy Fuels, 2004, 18 : 1584

[9] Mao D S, Yang W M, Xia J C, Zhang B, Song Q Y, Chen Q L. J Catal, 2005, 230: 140

[10] Kim J-H, Park M J, Kim S J, Joo O-S, Jung K-D. Appl Catal A, 2004, 264: 37

[11] Mao D S, Xia J C, Chen Q L, Lu G Z. Catal Commun, 2009, 10: 620

[12] Tang Q, Xu H, Zheng Y Y, Wang J F, Li H S, Zhang J. Appl Catal A, 2012, 413-414: 36

[13] Sierra I, Ereña J, Aguayo A T, Arandes J M, Bilbao J. Appl Catal B, 2010, 94: 108
[14] Fei J H, Hou Z Y, Zhu B, Lou H, Zheng X M. Appl Catal A, 2006, 304: 49

[15] Zheng J J, Ma J H, Wang Y, Bai Y D, Zhang X W, Li R F. Catal Lett, 2009, 130: 672

[16] Yang Q, Kong M, Fan Z Y, Meng X J, Fei J H, Xiao F-S. Energy Fuels, 2012, 26: 4475

[17] Nie R F, Wang J H, Fei J H, Hou Z Y, Zheng X M. Chin J Catal (聂仁峰, 王军华, 费金华, 侯昭胤, 郑小明. 催化学报), 2011, 32: 379

[18] Jiang S, Hwang J-S, Jin T H, Cai T X, Cho W, Baek Y S, Park S-E. Bull Korean Chem Soc, 2004, 25: 185

[19] Hassanpour S, Yaripour F, Taghizadeh M. Fuel Process Technol, 2010, 91: 1212

[20] Mao D S, Zhang B, Song Q Y, Yang W M, Chen Q L. Chin J Catal (毛东 森, 张斌, 宋庆英, 杨为民, 陈庆龄. 催化学报), 2005, 26: 365

[21] Khandan N, Kazemeini M, Aghaziarati M. Iran J Chem Eng, 2009, 6: 3

[22] Xue Z T, Zhang T, Ma J H, Miao H X, Fan W M, Zhang Y Y, Li R F. Microporous Mesoporous Mater, 2012, 151: 271

[23] Xu M C, Wang W, Seiler M, Buchholz A, Hunger M. J Phys Chem B, 2002, 106: 3202

[24] Wang L F, Zhang Z, Yin C Y, Shan Z C, Xiao F-S. Microporous Mesoporous Mater, 2010, 131: 58

[25] Triantafyllidis C S, Vlessidis A G, Nalbandian L, Evmiridis N P. Microporous Mesoporous Mater, 2001, 47: 369

[26] Ban S, van Laak A N C, Landers J, Neimark A V, de Jongh P E, de Jong K P, Vlugt T J H.J Phys Chem C, 2010, 114: 2056

[27] Vernimmen J, Meynen V, Herregods S J F, Mertens M, Lebedev O I, Van Tendeloo G, Cool P. Eur J Inorg Chem, 2011, 2011: 4234

[28] Xiao F-S, Wang L F, Yin C Y, Lin K F, Di Y, Li J X, Xu R R, Su D S, Schlögl R, Yokoi T, Tatsumi T. Angew Chem, 2006, 118: 3162

[29] Zhang C, Guo X W, Song C S, Zhao S Q, Wang X S. Catal Today, 2010, 149: 196

[30] Tan Y S, Zhao X, Pan J X, Xie H J, Niu Y Q. J Mol Catal (China) (谭猗 生, 赵霞, 潘俊轩, 解红娟, 牛玉琴. 分子催化), 1999, 13: 246

[31] Wang D Y, Wang J Q, Yang J H, Lu J M, Yin D H, Zhang Y. Chin J Catal (王迪勇，王金渠，杨建华，鲁金明，殷德红，张艳. 催化学报), 2012, 33: 1383

[32] Chu N B, Yang J H, Li C Y, Cui J Y, Zhao Q Y, Yin X Y, Lu J M, Wang J Q. Microporous Mesoporous Mater, 2009, 118: 169

[33] Zhang S H, Zhang B L, Gao Z X, Han Y Z.J Fuel Chem Technol (张素 红, 张变玲, 高志贤, 韩怡卓. 燃料化学学报), 2010, 38: 483

[34] Vishwanathan V, Jun K-W, Kim J-W, Roh H-S. Appl Catal A, 2004, 276: 251 


\title{
多级孔ZSM-5分子篮的合成及其在甲醇脱水制二甲醚反应中的应用
}

\author{
杨 琦 ${ }^{\mathrm{a}}$, 张海涛 ${ }^{\mathrm{b}}$ ， 猛 ${ }^{\mathrm{a}}$, 包秀秀 ${ }^{\mathrm{a}}$ ，费金华 ${ }^{\mathrm{a}}{ }^{*}$ ，郑小明 ${ }^{\mathrm{a}}$

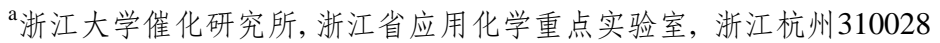 \\ $\mathrm{b}$ 中国石油兰州化工研究中心，甘肃兰州730060
}

摘要: 以四丙基氨为微孔模版剂, 阳离子高分子聚合物为介孔模版剂, 合成了具有多级介孔的ZSM-5分子笁, 并用于甲醇气相脱 水合成二甲醚. 结果表明, 加入阳离子高分子聚合物后, 合成的HZSM-5分子笁样品既保持了其MFI典型结构, 又呈现了多级介孔 特征; 随着阳离子高分子聚合物模板剂加入量的增加, 其多级介孔特征更为明显. 具有多级介孔的HZSM-5分子篮表现出比常规 微孔HZSM-5分子篮高的反应稳定性和二甲醚选择性, 这主要是由于其织构和酸性的双重作用.

关键词: 多级孔; HZSM-5分子篮; 表面酸性; 甲醇脱水; 二甲醚

收稿日期: 2013-03-05. 接受日期: 2013-05-13. 出版日期: 2013-08-20.

*通讯联系人. 电话/传真: (0571)88273283; 电子信箱: E-mail: jhfei@zju.edu.cn

基金来源：国家重点基础研究发展计划(973计划, 2007CB210207和2013CB228104); 国家高技术研究发展计划(863计划, 2007AA05Z415).

本文的英文电子版由Elsevier出版社在ScienceDirect上出版(http://www.sciencedirect.com/science/journal/18722067). 